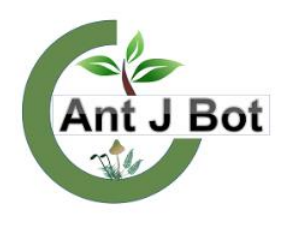

\title{
A New Mycena Record for the Mycobiota of Turkey
}

\author{
Yasin UZUN $^{1 *}$, Kenan DEMIREL ${ }^{2}$ \\ ${ }^{I}$ Karamanoğlu Mehmetbey University, Science Faculty, Department of Biology, Karaman, Turkey \\ ${ }^{2}$ Ordu University, Education Faculty, Department of Science and Mathematics Education,Ordu, Turkey \\ *yasinuzun_61@hotmail.com
}

\section{Türkiye Mikobiyotası İçin Yeni Bir Mycena Kaydı}

\begin{abstract}
The mycenoid species, Mycena pterigena (Fr.) P. Kumm. (Mycenaceae) is given as new record from Turkey. A brief description of the species and photographs related to its macro and micromorphologies are provided.
\end{abstract}

Key words: New record, Mycena, Trabzon, Turkey

Özet: Mycenoid bir tür olan Mycena pterigena (Fr.) P. Kumm. Türkiye’den yeni kayıt olarak verilmiştir. Türün kısa betimlemesi ve makro ve mikromorfolojilerine ilişkin fotoğrafları verilmiştir.

Anahtar Kelimeler: Yeni Kayıt, Mycena, Trabzon, Türkiye

\section{Introduction}

Mycena (Pers.) Roussel is a large genus of the family Mycenaceae Underw., with about five hundred known species worldwide (Kirk et al., 2008). The members of the genus are generally small mushrooms rarely exceeding a few centimeters in diameter and are characterised by very fragile and thin, membranous, conical to campanulate pileus; adnate to arcuate or decurrent lamellae; 1-4-spored basidia; intricate cystidia; white spore print; and smooth, hyaline spores. Almost all the members of the genus are saprotrophic and play a vital role in litter decomposition especially in forests and woodlands. Species of the genus have cosmopolitan distribution, and are usually determined on the debris of conifers, other woody plants and rarely on or among the debris of grasses, mosses, ferns (Pegler, 1986; Singer, 1986).

On 8 October 2016 some small pinkish mycena samples were collected from Uzungöl Nature Park within the Çaykara district of Trabzon province and identified as Mycena pterigena (Fr.) P. Kumm. Tracing the current checklists (Sesli and Denchev, 2014; Solak et al., 2015) and the latest macrofungal studies (Akata et al., 2016; Denğiz and Demirel, 2016; Kaya et al., 2016; Öztürk et al., 2016; Sesli et al., 2016; Taşkın et al., 2016; Uzun and Acar, 2016; Kaya et al., 2017; Uzun and Kaya, 2017; Uzun et al., 2017a; 2017b, 2017c), it was founded that the taxon has not been recorded from Turkey before.

The work aims to contribute to the mycobiota of Turkey.

\section{Materials and Method}

Macrofungi specimens were collected from Uzungöl Nature Park within the Çaykara district of Trabzon province during field trips in 2016 Morphological and ecological characteristics of the samples were recorded and they were photographed in their natural habitats. Then the specimens were transferred to the fungarium. Necessary microscopic investigations were carried out within the fungarium. Photographs related to micromorphology were also obtained during these investigations. The samples were identified with the help of Redhead (1984) and Miller (2004).
The specimens are kept at Karamanoğlu Mehmetbey University, Kamil Özdağ Science Faculty, Department of Biology.

\section{Results}

Basidiomycota R.T. Moore

Agaricales Underw.

Mycenaceae Roze

Mycena pterigena (Fr.) P. Kumm.

Synonym: Agaricus pterigenus Fr., Agaricus pterigenus Fr. var. pterigenus, Agaricus rubeolarius With., Mycena pterigena (Fr.) P. Kumm. var. pterigena.

Macroscopic features: Pileus 2-4 mm across, cylindrical when young then conical to campanulate, slighthly sulcate, translucent-striate, glabrescent to somewhat pruinose, pale salmon to pale pink, somewhat pale brownish at the centre. Flesh membranous, odor mild. Lamellae broadly adnate, decurrent, whitish to pale rose. Stem 10-35 $\times$ 0.2-0.3 mm, cylindrical, threadlike, concolorous with the cap or paler when young, then becomes transparent and grayish brown when mature, thicker at the base or somewhat bulbous (Fig. 1).

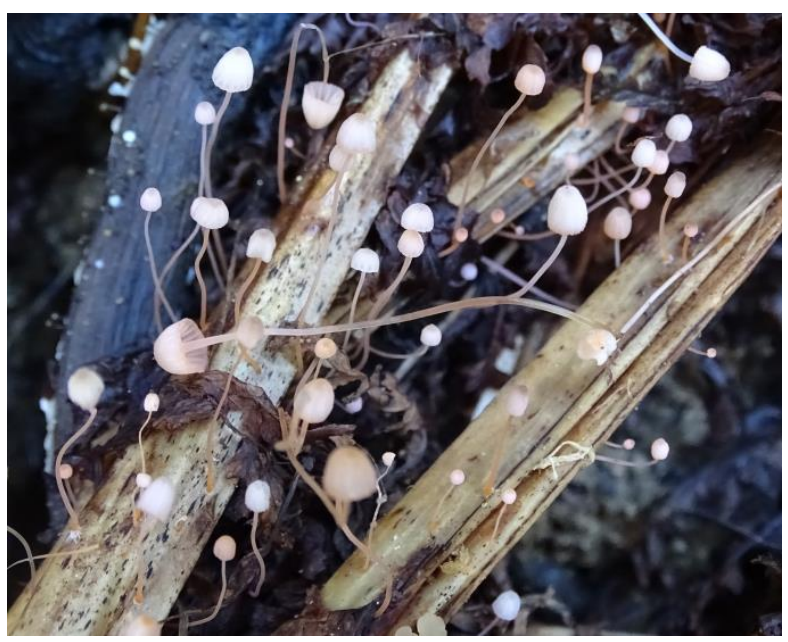

Figure 1. Basidiocarps of Mycena pterigena. 
Microscopic features: Basidia 20-25 × 8-10 $\mu \mathrm{m}$, broadly clavate, 4-spored (Fig. 2a). Cheilocystidia abundant, 19-24 $\times 11-15 \mu \mathrm{m}$, clavate to almost spherical, covered apically with fairly numerous, simple, rarely furcate, cylindrical projections up to $11 \mu \mathrm{m}$ long (Fig. 2b). Pileipellar hypha also covered with warts or short cylindrical excrescences
(Fig. 2c). Spores 7-10 × 3-5 $\mu \mathrm{m}$, narrowly to broadly elliptic, hyaline, smooth (Fig. 2d).

Specimen examined: Trabzon, Çaykara, Uzungöl Nature Park, roadside on dead Pteridium sp. stem, $40^{\circ} 36^{\prime} \mathrm{N}$ $40^{\circ} 19^{\prime} \mathrm{E}, 1470 \mathrm{~m}, 08.10 .2016$, Yuzun 5275.

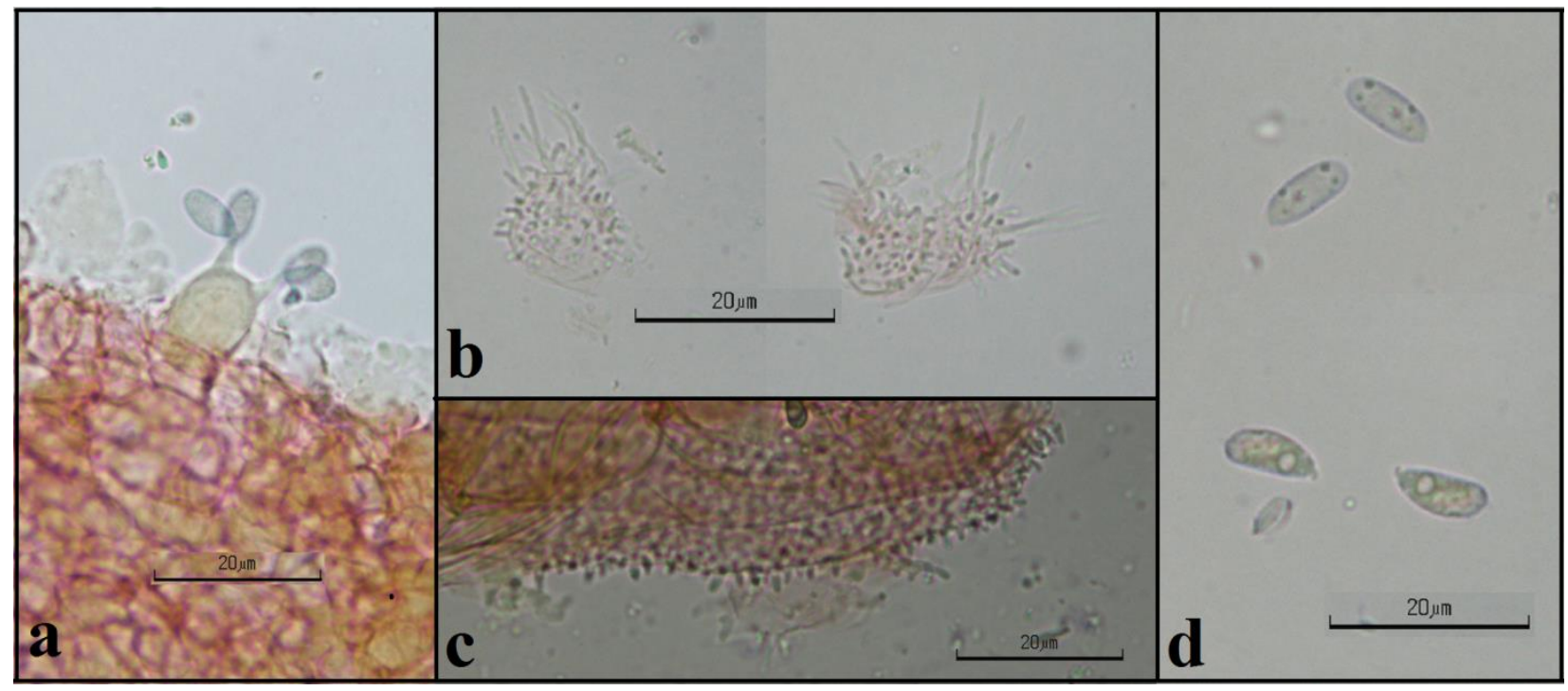

Figure 2. A four spored basidium (a), cheilocystidia (b), pileipellar hypa (c) and basidiospores (d) of Mycena pterigena.

\section{Discussions}

Current checklists on Turkish macromycota (Sesli and Denchev, 2014; Solak et al., 2015) indicate that 62 Mycena species have so far been recorded from Turkey. With this addition of Mycena, current species number of the genus Mycena increased to 63 .
Like Mycena pterigena, M. lohwagii also determined from fern associated habitats, but it has a greyish pileus when young, has a larger fruit body, shorter projections on its cheilocystidia, larger spores and colonizes rhizomes (Miller, 2004).

\section{References}

Akata I, Uzun Y, Kaya A (2016). Macrofungal diversity of Zigana Mountain (Gümüşhane/Turkey). Biological Diversity and Conservation 9(2): 57-69.

Cannon PF, Kirk PM (2007). Fungal Families of the World. Wallingford, UK: CAB International.

Denğiz Y, Demirel K (2016). Şirvan (Siirt) Yöresinde Yetişen Makrofunguslar Üzerinde Taksonomik Bir Araştırma. Yüzüncü Y1l University Journal of the Institute of Natural \& Applied Sciences 21(2): 112-123.

Kaya A, Uzun Y, Karacan İH, Yakar S (2016). Contributions to Turkish Pyronemataceae from Gaziantep province. Turkish Journal of Botany 40(3): 298-307.

Kaya A, Uzun Y, Karacan İH, Yakar S (2017). New additions to Turkish Helotiales and Orbiliales. Kastamonu Üniv. Journal of Forestry Faculty 17(2): (in print)

Kirk PM, Cannon PF, Minter DW, Stalpers JA (2008). Dictionary of the Fungi, 10th ed. Wallingford, UK: CAB International.

Miller A (2004). Trial Key to the Mycenoid Species in the Pacific Northwest. Pacific Nothwest Key Council, Victoria, USA.

Öztürk Ö, Doğan HH, Şanda MA (2016). Some new additions to Turkish mycobiota from Sakarya region. Biological Diversity and Conservation 9(1): 97-100.

Pegler DN (1986). Agaric flora of Sri Lanka. Kew Bulletin Additional Series 12: 1-519.

Redhead SA (1984). Two fern-associated mushrooms, Mycena lohwagii and M. pterigena, in Canada. Le Naturaliste Canadien 111: 439-442.

Sesli E, Denchev CM (2014). Checklists of the myxomycetes, larger ascomycetes, and larger basidiomycetes in Turkey. 6th edn. Mycotaxon Checklists Online. (http://www.mycotaxon.com/resources/checklists/sesli-v106-checklist.pdf): $1-136$.

Sesli E, Türkekul İ, Akata I, Niskanen T (2016). New records of Basidiomycota from Trabzon, Tokat, and İstanbul provinces in Turkey. Turkish Journal of Botany 40(5): 531-545.

Singer R (1986). The Agaricales in modern taxonomy. 4th ed. Königstein, Koeltz Scientific Books. 
Solak MH, Işıloğlu M, Kalmış E, Allı H (2015). Macrofungi of Turkey Checklist Vol II. Üniversiteliler ofset, İzmir.

Taşkın H, Doğan HH, Büyükalaca S, Colwez P, Moreau PA, O’Donnell K (2016). Four new morel (Morchella) species in the elata subclade (M. sect. Distantes) from Turkey, Mycotaxon, 131(2): 467-482.

Uzun Y, Acar İ, Akçay ME, Kaya A (2017a). Contributions to the macrofungi of Bingöl, Turkey. Turkish Journal of Botany 41(5): 516-534.

Uzun Y, Kaya A (2017). A Hypogeous Lactarius sp., New to Turkish Mycobiota. The Journal of Fungus 8(2): (in print).

Uzun Y, Kaya A, Karacan İH, Yakar S. (2017b). New additions to Turkish Hyaloscyphaceae. The Journal of Fungus 8(1): 13-19.

Uzun Y, Acar İ (2016). Peziza granularis Donadini Türkiye Mikobiyotası için Yeni Bir Kayıt. Yüzüncü Yı1 University Journal of the Institute of Natural \& Applied Sciences 21(1): 39-42.

Uzun Y, Kaya A, Karacan İH, Yakar S (2017c). New additions to Turkish Agaricales. Biological Diversity and Conservation 10(2): 8-13.

Cite this article: Uzun Y, Demirel K (2017). A New Mycena Record for the Mycobiota of Turkey. Anatolian Journal of Botany 1(1): 9-11. 